University of Nebraska - Lincoln

DigitalCommons@University of Nebraska - Lincoln

USDA National Wildlife Research Center - Staff

Publications

U.S. Department of Agriculture: Animal and Plant Health Inspection Service

July 2000

\title{
Mechanical Mouse Lure for Brown Treesnakes
}

Alexandria C. Lindberg

John A. Shivik

Larry Clark

USDA/APHIS/WS National Wildlife Research Center, larry.clark@aphis.usda.gov

Follow this and additional works at: https://digitalcommons.unl.edu/icwdm_usdanwrc

Part of the Environmental Sciences Commons

Lindberg, Alexandria C.; Shivik, John A.; and Clark, Larry, "Mechanical Mouse Lure for Brown Treesnakes" (2000). USDA National Wildlife Research Center - Staff Publications. 517.

https://digitalcommons.unl.edu/icwdm_usdanwrc/517

This Article is brought to you for free and open access by the U.S. Department of Agriculture: Animal and Plant Health Inspection Service at DigitalCommons@University of Nebraska - Lincoln. It has been accepted for inclusion in USDA National Wildlife Research Center - Staff Publications by an authorized administrator of DigitalCommons@University of Nebraska - Lincoln. 


\title{
Mechanical Mouse Lure for Brown Treesnakes
}

\author{
Alexandra C. Lindberg, John A. Shivik, and Larry Clark
}

\begin{abstract}
The importance of prey movement for stimulating feeding behavior of Brown Treesnakes was tested by using a mechanical mouse model in combination with and without prey odor. Prey movement was found to be important in stimulating brown treesnake feeding behavior. Prey movement combined with prey odor was not significantly different than prey movement alone. In the development of simple artificial lures based on the stimulus of live mice, visual lures lacking movement are likely to be ineffective. Lures that combine a visual moving stimulus with prey odor are likely to be the most effective artificial lure for trapping brown treesnakes.
\end{abstract}

$T^{4}$ HE Brown Treesnake, Boiga irregularis, a rear-fanged, nocturnal, arboreal colubrid, is an economic and ecological threat to the island of Guam as well as to other Pacific islands (Fritts et al., 1987; Savidge, 1987). Since its accidental early introduction in the 1950s (Rodda and Fritts, 1992a), the brown treesnake has caused a variety of problems, including the extirpation of Guam's avifauna and herpetofauna, numerous power outages, and loss of chickens and other domestic animals to predation (Fritts et al., 1987; Savidge, 1987; Rodda and Fritts, 1992b). To minimize the likelihood of these snakes being transported elsewhere, an intensive control trapping program is underway on Guam. Live mice are used as lures, and this presents logistical as well as animal care and maintenance problems for large-scale operations. In an effort to minimize the use of live animal lures, researchers have been developing synthetic chemical lures under the assumption that prey odors alone may serve as an attractant in concert with traps (Chiszar et al., 1988; Shivik and Clark, 1997; Shivik, 1998). However, to date, purely chemical lures have not compared favorably to the use of live mouse lures (Chiszar, 1990; Shivik and Clark, 1997; Shivik, 1998). Because previous studies have shown that both visual and olfactory cues are important in the foraging behavior of brown treesnakes, we attempted to incorporate visual and odor cues into the construction of an artificial lure to increase its effectiveness relative to the use of chemical cues alone. The importance of the visual aspects of movement on prey selection in snakes (Burghardt, 1966; Smith and Watson, 1972; Herzog and Burghardt, 1974) and lizards (Askew et al., 1970; Gluesing, 1983; Kaufman et al., 1996) is well known. Predators generally orient to moving versus nonmoving prey. Movement may be an important component of visual cues and the current effectiveness of live mice as lures suggests that mouselike movement may stimulate appetitive behavior in brown treesnakes. To test whether movement alone is a sufficient cue to stimulate appetitive behavior in brown treesnakes, a mechanical mouse was constructed, and the responses of the snakes to the moving model were recorded.

\section{Materials ANd Methods}

Brown treesnakes ( $n=37$ ) were captured in traps on Guam using live mouse lures between 19 June and 24 July 1998. Snakes were housed individually in $33 \times 24 \times 24 \mathrm{~cm}$ plastic tubs and allowed to acclimate for more than five days before testing. Snakes were provided with water during this time but were not fed. Experimental trials were run by videotaping snake behaviors for one hour after lures (protected by $7 \times 7 \times$ $20 \mathrm{~cm}$ hardware cloth holding boxes) were placed in the holding cages of individual snakes. Snakes were randomly assigned to four different treatments: a mechanical mouse covered with an unwashed mouse (M us musculus) skin; a mechanical mouse covered with artificial fur; a live mouse (M us musculus); and an empty control lure chamber. All snakes were used only once, and videotapes were scored at a later time.

The mechanical mouse lures contained an AA battery case connected to a 1.5V DC motor (Cer Mag Motors, FA 130; Shivik, 1999). The motor spun an unevenly weighted flywheel that caused the device to wobble rapidly. This wobble resulted in unpredictable movement of the approximately mouse-sized model as the spinning wheel occasionally hit the side of the lure container and bounced off.

We used one-way ANOVA to detect differences in the proportion of time snakes spent orienting toward each stimulus and used the Tukey method for multiple comparisons (Ott, 1993). To measure behaviors that might result in a snake entering a trap, we recorded two classes 


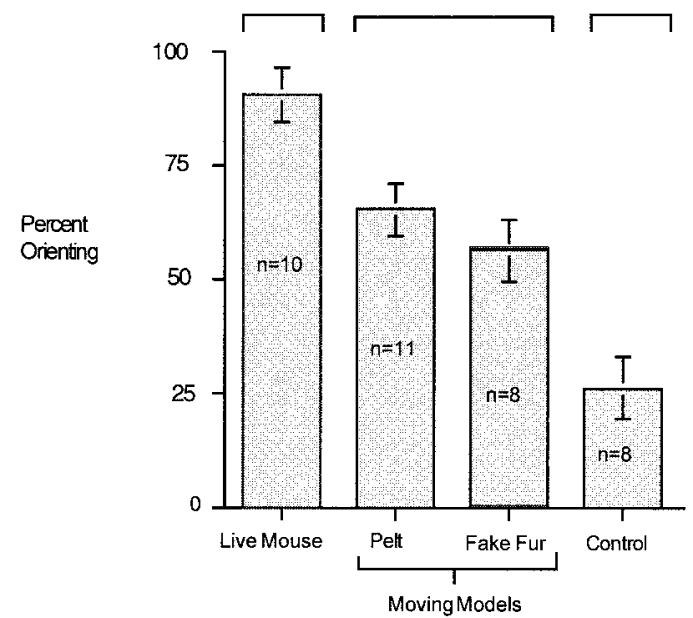

Fig. 1. Percentage of time brown treesnakes spent orienting toward a live mouse, a mechanical mouse covered with a mouse pelt, a mechanical mouse covered with fake fur, and an empty control box. Brackets encompass treatments that were not significantly ( $P<0.05$; Tukey test) different from each other.

of active behavior. Orienting behavior consisted of any behavior in which the snake was paying direct attention to the lure container. This included striking at, moving toward, constricting around, and probing the lure container. Investigating behaviors included any behaviors that occurred while the snake's attention was on something other than the treatment. The percent of time spent orienting was calculated as the time spent orienting divided by the total time spent orienting plus investigating.

\section{RESULTS AND Discussion}

We detected a difference in snake response to the various treatment types $\left(\mathrm{F}_{3,35}=12.38, \mathrm{P}\right.$ $<0.05$; Fig. 1). Snakes oriented toward live mice more than toward moving models (fake fur: $P<0.05$; pelt: $P<0.05)$ and control treatments $(P<0.05)$. Snakes oriented toward moving models more than control treatments (fake fur: $P<0.05$; pelt: $P<0.05)$.

Snakes use visual cues in general to a great extent (Czaplicki and Porter, 1974; Drummond, 1985), and visual cues associated with prey movement have been found to be sufficient to stimulate appetitive behavior without odor (Drummond, 1979; Burghardt and Denny, 1983; Lankford, 1989) as well as to override chemical cues in some instances (Phillips and Alberts, 1992; Heinen, 1995). The data from this experiment support the hypothesis that movement alone is sufficient to stimulate predatory behavior in brown treesnakes.
H owever, odor and visual stimuli may act synergistically to stimulate appetitive behavior in brown treesnakes; therefore the most effective lure may be one that incorporates both visual as well as odor cues (Shivik, 1998). Visual cues from prey have been shown to interact with chemical cues in an additive manner (Chiszar et al., 1981; Drummond, 1985), and combinations of various visual cues could also have an additive effect on snake foraging behavior. We hypothesized that adding real mouse skin to the moving model would result in increased orienting from snakes. The lack of a clear difference between fur-covered and fake-fur-covered models indicates that components of mouse skin did not provide sufficient odor cues to increase appetitive behavior. It is possible, however, that a difference may be found by examining more specific appetitive behaviors than the general behaviors that were examined in this particular experiment. Also, other mouse fluids may be more appropriate snake-attracting odors to be combined with future moving attractants.

Although the moving models in this study were attractive to brown treesnakes, they were not as attractive as a live mouse. Varying the speed and type of movement may increase the attractiveness of the stimulus resulting in a more effective lure (Burghardt and Denny, 1983). O ur experiment dealt only with one type of movement and a simplified model. Previous studies have shown that predators will select aberrant movement over normal movement (Gluesing, 1983). Studies of improved versions of the mechanical model, including models with adjustable activity cycles, are continuing. Ultimately, we believe that constructing moving models combined with an appropriate odor will result in an effective lure for brown treesnakes, thus replacing live mice in traps on Guam.

\section{ACKNOWLEDGMENTS}

We thank D. Vice, M. Pitzler, D. Rodriguez, and $\mathrm{H} . \mathrm{H}$ irsch at Andersen Air Force Base for logistic assistance on Guam. We thank L. Bjostad and W. Wright who suggested improvements to this article and provided help in so many other ways. This project was conducted with funds provided by the U.S. Department of Defense Legacy Project Number 1281 Development of Chemical Control Methods for Brown Treesnake $\mathrm{M}$ anagement, and the Department of $\mathrm{Bi}$ ology, Colorado State University. All research using brown treesnakes was done according to Colorado State University and the National Wildlife Research Center animal care protocol. 


\section{Literature Cited}

Askew, H. R., M. Musimecl, L. Sloane, and L. StePHAN. 1970. Effects of prey movement and background on predatory behavior of chameleons. Psychon. Sci. 20:17.

BuRghardT, G. 1966. Stimulus control of the prey attack response in native garter snakes. Psychon. Sci. 4:37-38.

- AND D. Denny. 1983. Effects of prey movement and prey odor on feeding in garter snakes. $Z$. Tierpsychol. 62:329-347.

CHISZAR, D. 1990. The behavior of the brown treesnake: a study in applied comparative psychology, $p$. 101-123. In: Contemporary issues in comparative psychology. D. A. Dewsbury (ed). Sinauer Associates, Inc., Sunderland, MA.

, S. V. TAYloR, C. W. Radcliffe, H. M. SMith, AND B. O'CONNELL. 1981. Effects of chemical and visual stimuli upon chemosensory searching by garter snakes and rattlesnakes. J. Herpetol. 15:415424.

K. Kandler, and H. M. Smith. 1988. Stimulus control of predatory attack in the brown treesnake (B oiga irregularis). 1. Effects of visual cues arising from prey. Snake 20:151-155.

CZAplicki, J. A., AND R. H. Porter. 1974. Visual cues mediating the selection of goldfish (Carassius auratus) by two species of Natrix. J. Herpetol. 8:129134.

Drummond, H. M. 1979. Stimulus control of amphibious predation in the northern water snake (Nerodia s. sipedon). Z. Tierpsychol. 50:18-44.

1985. The role of vision in the predatory behavior of natricine snakes. Anim. Behav. 33:206215.

Fritts, T. H., N. J. SCOtt JR., AND J. A. SAVIdge. 1987. Activity of the arboreal brown treesnake (Boiga irregularis) on Guam as determined by electrical outages. Snake 19:51-58.

GLUESING, E. A. 1983. Collared lizard predation: the effects of conspicuous morphology and movement. Copeia 1983:835-837.

HEINEN, J. T. 1995. Predator cues and prey responses: a test using eastern garter snakes (T hamnophis s. sirtalis) and American toads (Bufo a. americanus). I bid. 1995:738-741.

Herzo G JR., H. A., AND G. M. Burghardt. 1974. Prey movement and predatory behavior of juvenile west- ern yellow-bellied racers, Coluber constrictor mormon. H erpetologica 30:285-289.

Kaufman, J. D., G. M. Burghardt, and J. A. Phillips. 1996. Sensory cues and foraging decisions in a large carnivorous lizard, Varanus albigularis. Anim. Behav. 52:727-736.

LANKFORD, J. D. 1989. Stimulus control of foraging behavior in brown treesnakes (Boiga irregularis). J. Colorado-Wyoming Acad. Sci. 21:12.

OTT, R. L. 1993. An introduction to statistical methods and data analysis. Duxbury Press, Belmont, CA.

Phillips, J. A., and A. C. Alberts. 1992. Naive ophiophagous lizards recognize and avoid venomous snakes using chemical cues. J. Chem. Ecol. 18: 1775-1783.

Rodda, G. H., AND T. H. Fritts. 1992a. Sampling techniques for an arboreal snake, Boiga irregularis. Micronesia 25:23-40.

, AND - 1992b. The impact of the introduction of the colubrid snake Boiga irregularis on Guam's lizards. J. Herpetol. 26:166-174.

SAVIDGE, J. A. 1987. Extinction of an island forest avifauna by an introduced snake. Ecology 68:660-668.

SHIVIK, J. A. 1998. Brown treesnake response to visual and olfactory cues. J. Wildl. Manag. 62:105-111.

- 1999. Carrion, context and lure development: the relative importance of sensory modalities to foraging brown tree snakes (Boiga irregularis). Unpubl. Ph.D. diss., Colorado State Univ., Fort Collins.

, AND L. Clark. 1997. Carrion seeking in brown tree snakes: importance of olfactory and visual cues. J. Exp. Zool. 279:549-553.

SMIth, G. C., AND D. Watson. 1972. Selection patterns of cornsnakes, Elaphe guttata, of different phenotypes of the house mouse, M us musculus. Copeia 1972:529-532.

(ACl) Department of Biology, Colorado State University, Fort Collins, Colorado 80523; ANd (JAS, LC) UNITED STATES DEPARTment of Agriculture, National Wildlife Research Center, 4101 LaPorte Avenue, Fort Collins, Colorado 80521. E-mail: ( JAS) john.shivik@usda.gov. Send reprint requests to JAS. Submitted: 23 June 1999. Accepted: 11 Nov. 1999. Section editor: A. H. Price. 